\title{
Isolation, and Molecular Identification of Goat Pox Virus in Suez Canal Area, Egypt
}

Mona R. Fares*, Mohamed Fawzy**, Momtaz A. Shahin*, Mohamed S. Elshahidy***

Department of Virology, Animal Health Research Institute (AHRI), Dokki, Giza 12611, Egypt **Department of Virology, Faculty of Veterinary Medicine, Suez Canal University, Ismailia 41522, Egypt

**Corresponding author: Mohamed Fawzy,

Mohamed_mohamed4@vet.suez.edu.eg

\begin{abstract}
:
Goat pox virus is a highly contagious viral disease of goats causing huge economic losses in animal productivity. This study was designed for isolation, identification and molecular characterization of goat pox virus in Suez Canal area. From a total of 200 goats in 6 flocks located in Suez Canal provinces; Ismailia, Suez, and Port Said, about 26 skin scab samples mixed in 6 pools and 116 serum samples were collected in the period from 2017 to 2019. Typical pock lesion were observed in $4 / 6 \quad(66.66 \%)$ of pooled samples, while the rest of the sample $2 / 6(33.33 \%)$ showed no pathological changes on the chorioallantois membrane (CAM) of 11-13 days old embryonated chicken eggs (ECE). A total of 18 positive samples out of 116 examined sera were recorded by AGPT with a total positive percentage of $15.52 \%$. Goat pox virus antibody titer was higher in vaccinated animals than non-vaccinated animals. Goats less than 6 months old exhibited higher antibody titer than animals more than 6 months old. Conventional PCR was done for 3 pooled goat pox isolates with capripox specific primers for P32 (primer 1) and 3 pooled isolate for p32 (primer 2) one pooled isolate for RPO30 gene. PCR were carried out for goat pox virus isolates recovered from animal skin crusts and CAM harvest of infected eggs. The size of the PCR products by $1.5 \%$ gel electrophoresis with capripox specific primers for P32 (primer 1, 2) and RPO30 gene were 89 and 390 and 151 base pairs respectively.
\end{abstract}

\section{Introduction}

Goat pox virus (GTPV) is a contagious viral disease of goats. It is a notifiable disease, listed by OIE and Animal and Plant Health Inspection Agency (USDA) (USDA, 2002). It is a DNA virus, recorded as one of the largest viruses (170-260 nm x 300-450 $\mathrm{nm})$, belonged to genus Capripoxvirus; including lumpy skin disease of cattle, subfamily; Chrodopoxvirinae, family Poxviridae (Matthews, 1982). 
GTPV have worldwide distribution and endemic throughout southwest and central Asia, northern and central Africa, and Middle East countries including Egypt (Maksutov et al., 2013).

GTPV transmitted directly by aerosols, close contact with infected animals and indirectly by abrasions (Kitching and Carn, 2004). Poor conditioned animals, overstock, inadequate feeding, poor management, and faulty use of vaccination considered the main causes for GTPV outbreak (SheikhAli et al., 2004). Mechanical transmission by arthropod vectors also recorded (Sherry et al., 2014). GTPV produce unusual economic loss due to its high morbidity, mortality rate, reduced milk and meat production, abortions, poor wool and skin quality and trade restrictions (Yeruham et al., 2007).

Young animals are the most susceptible with mortality rates ranged between $50 \%$ and $70 \%$ due to pneumonia (Balinisky et al., 2008). GTPV characterized by fever, anorexia, depression, inflammation of the mucous membranes of the eyes and nose, respiratory distress with appearance of pox lesions as popular, pustular, scab stages on areas devoid of hair such as checks, lips, nostrils, inner aspect of the thigh, under the tail, and enlargement of superficial lymph nodes (Diallo and Viljeon 2007) in which the skin lesions usually heal within 5-6 weeks (Davies and Otema, 1981). P.M lesions of GTPV can develop in lung, spleen, lymph nodes, and other internal organs. Mucous membranes of affected organ may become ulcerate or slough and necrotic.

The diagnosis of goat pox virus is based on clinical symptoms followed by laboratory assurance. Several laboratory techniques are based on virus isolation and serological tests like immunofluorescence, immunoprecipitation, virus neutralization, and ELISA (Oguzoglu et al., 2006). PCR is a simple, rapid and specific techniques have been developed to detect Capripoxviruses (CPV) DNA in infected cell culture supernatants, biopsy samples (Heine et al., 1999). It is used to overcome limitations resulted from virus isolation (Ireland and Binepal, 1998). In this study, Virus isolation in ECE by CAM route (11-13 days old) followed by Identification with AGPT and PCR based method using specific primer amplification of P32 gene were carried out.

\section{Materials and Methods \\ Samples}

A total of 200 goats in 6 flocks located adjacent to Suez Canal in three provinces in the eastern of Egypt including, Ismailia, Suez, and Port Said were used in this study. Twenty-six skin scab samples mixed in 6 pools and 116 serum samples were collected from different outbreaks in 2017-2019. 
The samples were processed, and kept in $-70^{\circ} \mathrm{C}$ deep freezer until used.

\section{Virus isolation}

Pox virus isolation was carried out according to the method described by (Mahmoud et al., 2010), Scabs, which were formed over the face, fatty tail, and the rest of the body of the affected animals, were collected as a source of the virus and used for egg inoculation. The scabs were ground in $1 \mathrm{ml}$ sterile phosphatebuffered saline (PBS) containing antibiotics (penicillin $100 \mathrm{IU} / \mathrm{ml}$, streptomycin $100 \mu \mathrm{g} / \mathrm{ml}$, and kanamycin $50 \quad \mu \mathrm{g} / \mathrm{ml}$ ). The suspension was frozen and thawed 3 times, and then centrifuged at 2000 rpm for $30 \mathrm{~min}$. Then, $0.1 \mathrm{ml}$ of the supernatant was inoculated in SPFECE (11-13 days old age). Sterile PBS was inoculated in SPF-ECE and used as negative control. Inoculated eggs were incubated at $37^{\circ} \mathrm{C}$ under suitable percentage of humidity with daily candling. After five days, the allantoic fluids, and chorioallantoic membranes (CAMs) were collected carefully. CAMs were examined for the presence of the characteristic pock lesions of Poxviridae family.

Agar gel immunodiffusion (AGID)

The test was carried out according to OIE, 2010. An agar gel immunediffusion (AGID) test has been used for detecting the precipitating antigen of Capri poxvirus in skin scabs or inoculated CAM. Agarose $(1 \%)$ is prepared in borate buffer,
PH 8.6, dissolved by heating, and 2 $\mathrm{ml}$ is poured on to a glass microscope slide $(76 \times 26 \mathrm{~mm})$. When the agar has solidified, wells are cut to give a six-well rosette around a central well. Each well is 5 $\mathrm{mm}$ in diameter, with a distance of $7 \mathrm{~mm}$ between the middle of the central well and the middle of each peripheral well. The wells are filled as follows: $18 \mu \mathrm{l}$ of the lesion suspension is added to three of the peripheral wells, alternately with positive control antigen, and $18 \mu \mathrm{l}$ of positive Capri poxvirus control serum is added to the central well. The plates are placed in a humidified chamber at room temperature for 48 hours, and examined for visible precipitation lines using a light box. The test material is positive if a precipitation line develops with the control serum that is confluent with that produced by the positive control antigen.

\section{DNA extraction}

Total DNA either from skin nodules or from infected CAMs were extracted by using QIAamp DNA extraction kit (QIAGEN, UK) according to manual of the manufacturers. The kit was obtained from QIAGEN Incorp, USA Cat. No.51304.

\section{Conventional Polymerase chain reaction (PCR)}

Protocol and Cycling conditions of conventional PCR for goat pox virus genes were carried out according to the method described by Mangana-Vougiouka et al. (2000). Forward primer AAA ACG 
GTA TAT GGA ATA GAGTTG GAA, reverse primer AAA TGA AACCAATGG ATG GGATA; this primer gives amplicon size of $89 \mathrm{bp}$ (Tuppurainen et al.,2012). The test was carried out in $25 \mu \mathrm{l}$ total reaction volume. (12.5 $\mu$ l Maxima Hot Start Green PCR Master Mix (Fermentas, USA), $0.5 \mu \mathrm{l}$ of each primer $(10 \quad \mathrm{pmol} / \mu \mathrm{l}), 5 \mu \mathrm{l}$ of extracted DNA, and $6.5 \mu \mathrm{l}$ of nuclease free water. Negative control of nuclease free water and positive control of reference antigen were used. The amplification conditions were initial denaturation at $95^{\circ} \mathrm{C}$ for $4 \mathrm{~min}$, followed by 40 cycles of denaturation at $95^{\circ} \mathrm{C}$ for $30 \mathrm{~s}$, annealing at $55^{\circ} \mathrm{C}$ for $30 \mathrm{~s}$, and extension at $72^{\circ} \mathrm{C}$ for $30 \mathrm{~s}$ and final extension at $72^{\circ} \mathrm{C}$ for $5 \mathrm{~min}$ in a thermocycler (Eppendorf AG, Hamburg, Germany). The PCR products were electrophoresed on $2 \%$ agarose gel for $1 \mathrm{~h}$ at $100 \mathrm{~V}$.

\section{Results and discussion: \\ Virus isolation}

Egg inoculation of skin nodules and crusts collected from infected goats with pox virus revealed characteristic pock lesions with thickening of CAM of inoculated eggs with edema and hemorrhages (Fig. 1 C). Typical pox lesion were observed in 4 out of 6 pooled samples with isolation percentages of $(66.66 \%)$ (Fig. 1), while the rest of the samples 2/6 (33.33\%) showed no pathological changes on the CAM. These 6pools were collected from skin crusts and nodules of 26 infected goats. The findings of isolation were in agreement with Mahmoud and Khafagi, (2016) Who found that Egg inoculation revealed characteristic pock lesions for poxviruses in 30/37 (19 sheep and 11 goats) $(81.08 \%)$, While the rest of the sample (7/37 [18.92\%]) showed no pathological changes on the CAM.

\section{Identification of GTPV isolates by} AGPT

A total of 18 positive goats out of 118 examined sera were recorded by AGPT with a total percentage of 15.52. These results were in accordance with that obtained by Sharma et al., (1988), who reported that 29 out of the $604(4.8 \%)$ samples were positive by the AGPT.

Antibody titer of goat pox in vaccinated goats documented in table 1, was higher than the nonvaccinated animals, these results coincide with the fact that vaccine represent as immune stress pressure. The same results obtained by Eman Abd-Elfatah et al., (2019) Presence of specific goat pox antibodies in non-vaccinated animals shown in table 1, may be due to the close contact of animals during outbreaks. Molecular diagnosis of goat pox virus by conventional PCR and gel electrophoresis:

PCR technique is more effective for diagnosis of GTPV and SPV in field samples when combined with restriction enzyme analysis (REA) (Rao and Bandyopadhyay, 2000). 
Conventional PCR was done for 3 pooled goat pox isolates with capripox specific primers for $\mathrm{P} 32$ (primer 1) and 3 pooled isolate for p32 (primer 2) one pooled isolate for RPO30 gene. PCR were carried out for goat pox virus isolates recovered from animal skin crusts and CAM harvest of infected eggs. The size of the PCR products by $1.5 \%$ gel electrophoresis with capripox specific primers for P32 (primer 1, 2) and RPO30 gene were $89, \quad 390$ and 151 base pairs respectively (figure $2, \mathbf{3 , 4}$ ).
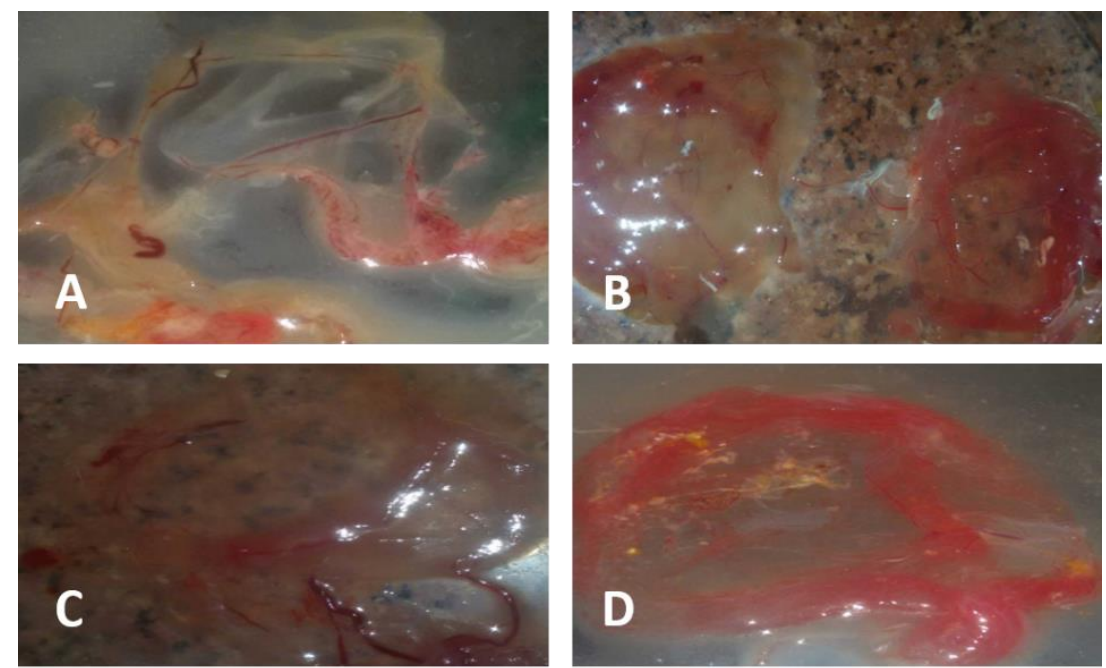

Figure (1): Isolation of the collected samples on CAM of ECE; (A): Thickening, edema of CAM of eggs inoculated with goat pox virus. (B): Rounded white pock lesion in CAM and hemorrhages due to goat pox virus. (C): Hemorrhages and edema of CAM with minute pock lesion. (D): White necrotic foci with wide and large pock lesion in CAM.

Table (1): Screening of pox antibodies in goat serum by AGPT

\begin{tabular}{|c|c|c|c|c|}
\hline \multirow{2}{*}{$\begin{array}{l}\text { Province/ } \\
\text { Species }\end{array}$} & \multirow{2}{*}{$\begin{array}{c}\text { Total No. of serum } \\
\text { samples }\end{array}$} & \multirow{2}{*}{$\begin{array}{l}\text { Vaccination } \\
\text { Status }\end{array}$} & \multicolumn{2}{|c|}{ AGPT results } \\
\hline & & & $+\mathrm{ve}$ & $\%$ \\
\hline $\begin{array}{l}\text { Ismailia } \\
\text { Goats }>\text { 6-months } \\
\text { Goats }<\text { 6-months }\end{array}$ & $\begin{array}{l}20 \\
18\end{array}$ & $\begin{array}{l}- \\
+\end{array}$ & $\begin{array}{l}3 \\
7\end{array}$ & $\begin{array}{c}15 \\
38.88\end{array}$ \\
\hline $\begin{array}{l}\text { Port Said } \\
\text { Goats }>\text { 6-months } \\
\text { Goats }<6 \text {-months }\end{array}$ & $\begin{array}{l}25 \\
12\end{array}$ & - & $\begin{array}{l}2 \\
1\end{array}$ & $\begin{array}{c}8 \\
8.33\end{array}$ \\
\hline $\begin{array}{ll}\text { Suez } & \\
& \text { Goats }>\text { 6-months } \\
\text { Goats }<6 \text {-months }\end{array}$ & $\begin{array}{l}22 \\
19\end{array}$ & - & $\begin{array}{l}1 \\
4\end{array}$ & $\begin{array}{c}4.54 \\
21.05\end{array}$ \\
\hline Total & 116 & & 18 & 15.52 \\
\hline
\end{tabular}




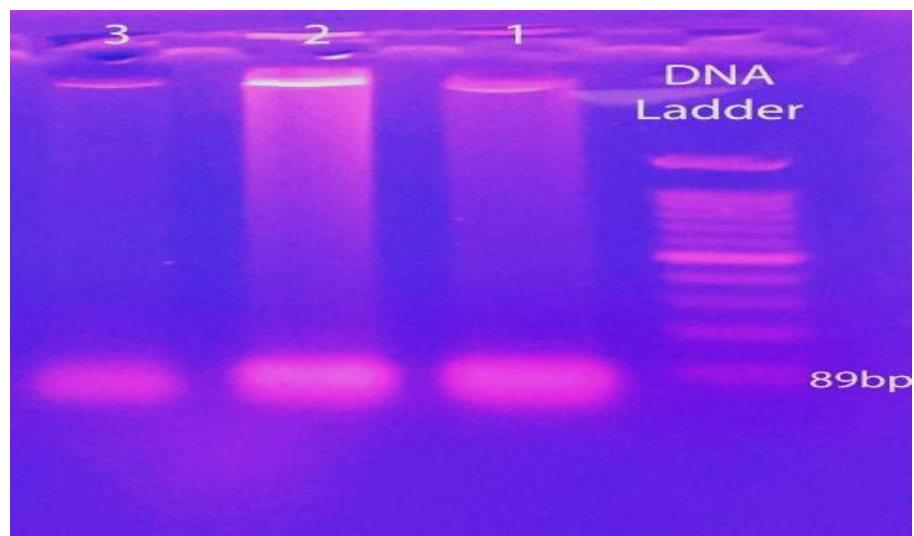

Fig. (2): Detection of goat pox P32 gene by gel electrophoresis at ( $89 \mathrm{bp}$ ) using primer1, Lane 1, 2, 3, are GPV positive samples. DNA Ladder: (100$1500 \mathrm{bp}$ ).

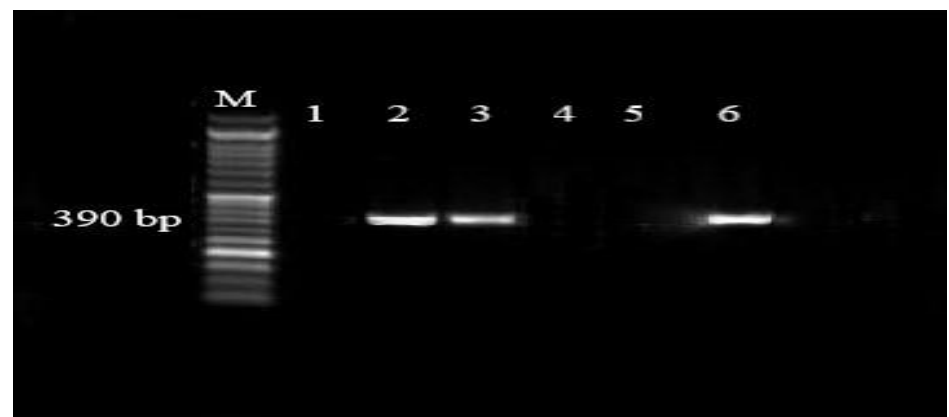

Fig. (3): Detection of goat pox P32 gene by gel electrophoresis at (390 bp) using primer 2, M: DNA Marker: (50-1500bp), Lane 1: blank well , lane 2,3 GTPV positive samples, Lane 4: GTPV negative sample, lane 5: negative Control, Lane 6: positive control.

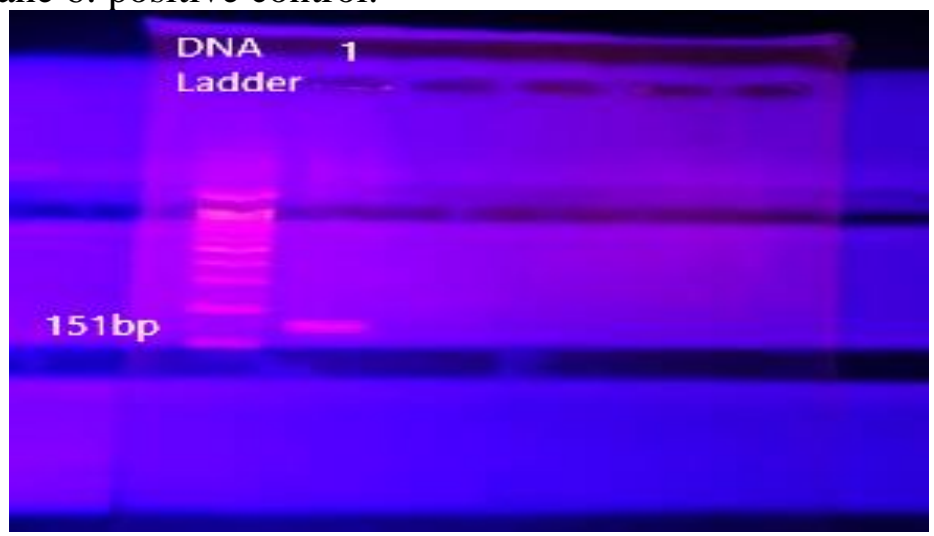

Fig. (4): Detection of goat pox RPO30 gene by gel electrophoresis, Lane 1: show positive GTPV sample. 
References

Balinsky, C.A.; Delhon, G.; Smoliga, G.; Prarat, M.;French, R.A.; Geary, S.J.; Rock, D.L. and Rodriguez, L.L.(2008): Rapid preclinical detection of sheep pox virus by a Real-time PCR assay. J. Clin. Microbiol., 46: 438-442.

Davies, F. G. and C. Otema. (1981): Relationships of capripoxviruses found in Kenya with two Middle Eastern strains and some orthopox viruses. Res.Vet. Sci. 31(2):253-255.

Diallo, A. and Viljoen, G.J. (2007): Genus Capripoxvirus. In: Mercer, A.A., Schmidt, A. and Weber, O., editors. Poxviruses. Birkhauser, Basel, Switzerland. p167-181.

Eman, B. Abd-Elfatah; Mamdouh, F. El-Mekkawi; Emad, A. Aboul-Soud; Elshaima, M. Fawzi and Sherif A. El-Soally (2019): Immunological response of a new trivalent capripoxvirus vaccine in pregnant ewes and does. Slov. Vet. Res. 2019; 56 (Suppl 22): 445-55 Original Research Article DOI 10.26873/SVR-782-2019.

Heine, H.G.; Stevens, M.P.; Foord, A.J. and Boyle, D.B. (1999): A capripoxvirus detection PCR and antibody ELISA based on the major antigen P32 the homolog of the vaccinia virus $\mathrm{H} 3 \mathrm{~L}$ gene. J. Immunol. Methods; 227: 187-96.

Ireland, D.C. and Binepal, Y.C. (1998): Improved detection of capripoxvirus in biopsy samples by PCR. J. Virol. Methods; 74:1-7.
Kitching, R.P. and Carn, V.M. (2004): Sheep pox and Goat pox. Office International des Epizooties Manual of Diagnostic Tests and Vaccines for Terrestrial Animals (mammals, birds, and bees). OIE, Paris.

Mahmoud, A.M.; Abdelrahman, A.K. and Soliman, H. (2010): Molecular and virological studies on contagious pustular dermatitis isolates from Egyptian sheep and goats. Res. Vet. Sci., 89: 290-294.

Mahmoud, M.A. and Khafagi, M.H. (2016): Detection, identification and differentiation of sheep pox virus and goat pox virus from clinical cases in Giza Governorate, Egypt. Veterinary World. 2016; 9(12):1445-1449.

Maksyutov, R.A.; Gavrilova, E.V.; Agafonov, A.P. and Taranov, O.S. (2013): An outbreak of Sheep pox in Zabajkalskij kray of Russia. Transbound. Emerg. Dis. 62(4): 453-456. https :// doi.org/10.1111/tbed.12176.

Mangana-Vougiouka, O.; Markoulatos, P.; Koptopoulos, G.; Nomikou, K.; Bakan -dritsos, N. and Papadopoulos, P. (2000): Sheep poxvirus identification from clinical 72 specimens by PCR, cell culture, immunofluorescence and agar gel immunoprecipitation assay. Mol. Cell. Probes 14: 305-310.

\section{Matthews, R.E.}

(1982):

Classification and nomenclature of viruses. Intervirology 17: 1-99.

Oguzoglu, T.C.; Alkan, F.; Ozkul, A. and Atalay-Vural S. (2006): A 
Sheeppox virus outbreak in Central Turkey in 2003: Isolation and Identification of Capripoxvirus. Veterinary Research Communications $30 \quad$ (8): 965971.https://doi.org/10.1007/s11259006-3259-7.

OIE (Office International des Epizooties), (2010): Sheep pox and goat pox Chapter 2.7.14 .

OIE, (2017): Internationale des Epizooties (World Health Organization for Animals) Manual of Diagnostic Tests and Vaccines for Terrestrial Animals. Sheep Pox and Goat Pox. 7: 13: 1-12.

Parthiban, M.R.; Govindarajan, S.; Manoharan, V. and Purushothaman N.D.J. (2005): Comparative sequence analysis of diagnostic PCR amplicons from Indian Sheep pox virus. Vet. Arhiv. 75: 203-209.

Rao, T.V.S. and Bandyopadhyay, S.K. (2000): A comprehensive review of goat pox and sheep pox and their diagnos. Animal Health Research Reviews, 1: 127-136. https://doi.org/ 10.1017/s1466252300000116.

Santhamani, R.; Yogisharadhya, R.; Venkatesan, G.; Shivachandra, S.B.; Pandey, A.B.and Ramak, M.A. (2013): Detection and differentiation of sheep pox virus and goat pox virus from clinical samples using $30 \mathrm{kDa}$ RNA polymerase subunit ( $R P O 30$ ) gene based PCR. Veterinary World. 2013; 6(11):923-925.
Sharma, B.; Negi, B.S.; Pandey, A.B.; Bandyopadhyay, S.K. and Shankar,H. (1988): Detection of goat pox antigen and antibody by the CIE test. Tropical Animal Health and Production 20: 109-113.

Sheikh-Ali, M.A.; Hamad, M.E.; Ali, B.H. and Saeed, A.W. (2004): Alterations in some epidemiological patterns and virus heterogeneity recently observed in sheep pox outbreaks in the Sudan. Vet. Arhiv. 74: 341-350.

Sherry, L.H.; Chen, P.; McFadden, G. and Rothenburg, R.S. (2014): Poxviruses and the evolution of host range and virulence. Infect. Genet. Evol., 21: 15-40.

Tuppurainen, E. S. M.; Lubinga, j. C.; Stoltsz, w. H.; Troskie, m.; Carpenter, S. T.; coetzer, j. A.w.; Venter, e. H. And Oura, c. A. L. (2012): Mechanical transmission of lumpy skin disease virus by Rhipicephalus appendiculatus male ticks. Cambridge University Press 2012. Epidemiol. Infect. (2013), 141, 425-430. doi:10. 1017/ S09502 68812000805.

USDA. Agricultural bioterrorism act of (2002): Fedl Regist. 67(155): 52383-52389.

Yeruham, I.; Yadin, H.; Van Ham, M.; Bumbarov, V.; Soham, A. and Perl, S. (2007): Economic and epidemiological aspects of an outbreak of sheep pox in a dairy sheep flock. Vet. Rec. 160: 236237. 


\section{العزل والتوصيف الجزيئي لفيروس جدري الماعز في منطقة قناة السويس، مصر}

فيروس جدري الماعز هو مرض فيروسي شديد العدوى في الماعز يتسبب في خسائر اقتصادية هائلة

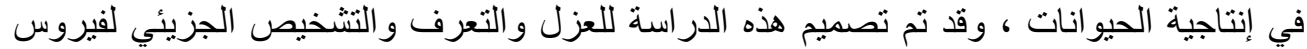

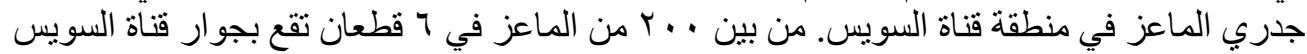

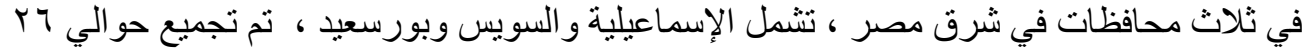

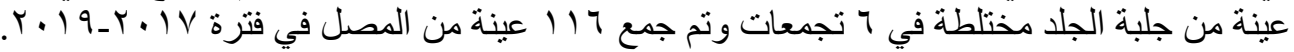

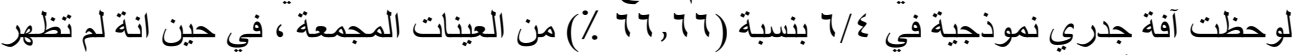

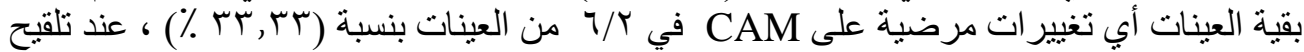

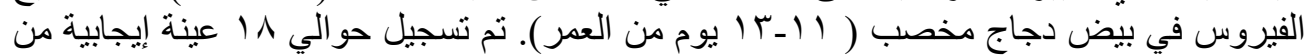

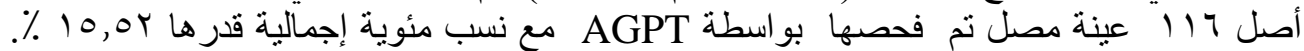

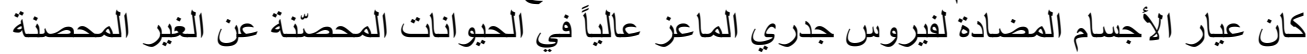

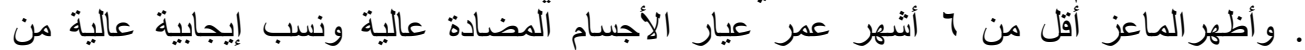

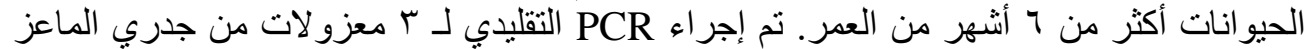

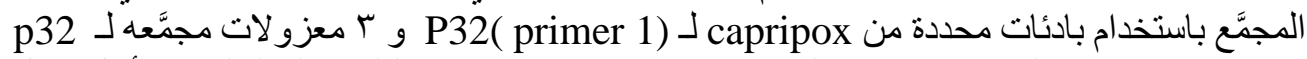
(primer 2) فيروسات جدري الماعز المستخرجة من فشور جلد الحيوان وحصاد

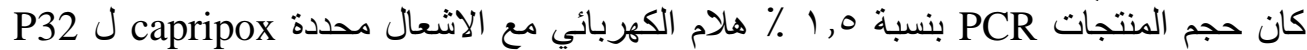

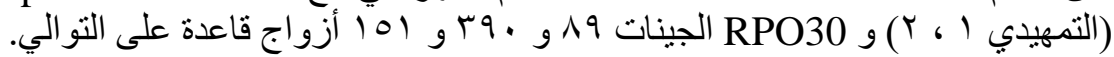

